\title{
The Role of Religion in the Social Inclusion of Arab Refugees and Immigrants in Europe
}

\author{
Ouael Sarsour* \\ PhD candidate at Aegean University of Greece, School of Social Sciences. Department of Sociology. University \\ Hill, 81132 Mytilene, Greece
}

*Corresponding Author: Ouael Sarsour, PhD candidate at Aegean University of Greece, School of Social Sciences. Department of Sociology. University Hill, 81132 Mytilene, Greece

\section{INTRODUCTION}

This study deals with the specific aspect of the intercultural issue involved in the social inclusion of Arab refugees and migrants in the countries of the European Union. that is the issue of religion. The concept and perception of religion will be studied, but also the main ideologies involved with religion as intercultural features in relation to migration and refugees. It will analyze their utility, skill, and influence on different societies and role playing in the social inclusion of migrants and refugees. The importance of religion and impact of religious beliefs, traditions and ideologies is a broad and complex study, but it should be mentioned here because of the importance of these factors in social inclusion, as most refugees and migrants in Europe come from Arab and Muslim countries, which are very conservative societies compared to Europe, character and values.

\section{THE CONCEPT OF RELIGION}

Religion is a set of ideas, principles, values, and beliefs that believe a socially, verbal and practical. Religion gives an explanation to a person for the purpose of his presence on this land, as it revolves around the idea of a deity, deals largely with morals and defines frameworks that regulate some or all aspects of those who believe tained. Religion has a significant impact on humans and generally in life, it contributes mainly to transforming the course of life and deep changes in his personality, to the present and in the future, presenting new prospects to the human face for many sensitive issues that disrupt the thought of and may prevent him from proceeding to his life.

Weber defines religion as interests and interests and not as ideas that dominate a society, consider it cosmean, created by ideas, and define the bases and channels through which the dynamics of interests and interests are being developed, which are very Specific consequences and impact on everyday economic, social, political and cultural life. According to Weber, religion is born of human action, affects and affected by the social structure. Weber believes that the importance of religion is based on the magic that stems from how to think of primitive cultures and children, while subjects have a relationship between neighborhood and power transaction with forces.

Anthropologist Taylor thought that religion is faith in spiritual entities. Based on his theoretical point of view in anemismism or awarding, that is, the faith of primitive people in souls in nature and give people, plants, animals, celestial bodies. Taylor believed that religions have evolved from early anemism, to ancestralism in the worship of many assemblies (polytheism) and then to the worship of one god (monotheism as a development. While Frazer, he formulated the theory of the transition of mankind from primacy to culture Through three stages, magic, religion, and science. Frazer considers that religion is the assembling forces that are considered superior to man.

Movements of large population groups of immigrants and refugees in the European area in the context of safe space and job finding, carrying out different cultural and ethnic diversity as regards language and religion, leads to policies including all immigrants, irrespective of race, culture and Religion in their effort smooth integration into the European acquis.

The 1951 Convention considers that the persecution due to religion was an integral and acceptable element of refugee definition. International refugee law considers that the religion from the 
fundamental rights of man, which may include freedom of thought, consciousness or faith. In the broad sense, it covers acts of omission or refusing worship of a religion or faith in a particular religion. Asylum applications based on religion as a reason for fear of persecution often involve allegations of discrimination. International human rights law prohibits discrimination refugees for religious reasons.

\section{RELIGION IN ARAB SOCIETIES}

For Arabs, religion is considered by the most important intercultural features. Refugees and migrants as they enter Europe, experience liberalism, which is contrary to their religion. For Europe, this conflict of liberalism, the conservative social model and religion is historically known, and society has taken it for decades, while for Arabs immigrants, this conflict is new, including those resulting from Islamic countries tained.

Most Arab countries due to society control, and the pressure of the clowns, took from liberalism the axis of economic and class, and ignored the axis of social and politics. The rate of religiosity, between Muslims and Christians of the Arabs, is higher than these European countries. Customs and traditions are largely religious and have significant moral power in cleric, especially in Muslims than in Europe, and this complicates the social behaviors of refugees and immigrants.

\section{RELIGION IN EUROPE}

Europe as a society is characterized by democracy, secularity, equality values, and humanity, features it won, after passing a long time with painful and harsh historical experiences, and has largely managed to set a religious power boundaries resist the fundamental values of European society.

The institutions in Europe are aligned with this social contract. On the other hand, European societies increase the profile of personal freedom, which is an essential part of the liberal system and therefore protected modern European laws and values.

As a result, man has freedom in his personal behavior, thought, religious or non-religious faith and his personal relationships. European societies have failed to get rid of the power of social and religious control.

Perhaps the rights of women and sexual freedom are one of the most indicatively sensitive and immeasurable for new refugees and immigrants in Europe, and as found in the present investigation, and by their inputs, the majority of them come from the Arab and Islamic States of Syria, Iraq and Afghanistan. But these societies are mainly preservative and the behavior of the person is governed by many social customs.

On the other hand, statistical surveys that show the link and relationship of Europe's pulp with religion show that, in the Netherlands, more than half of the population at $54 \%$ never monitors the Divine Operation of a Bond, followed by United Kingdom at 36\%. While in low rates are Germany with $21 \%$, Italy with $12.5 \%$. These rates demonstrate the collapse of religion with its traditional and institutional mood in the dimensions of culture, ethics, emotion, and to conclude that Europeans in their religious traditions and beliefs are involved without believing or believe without participating. With a gradual reduction in religion influence in Europe, it loses its ability to shape identities, and to a greater degree its ability to affect political ideologies.

\section{RELIGION AND POLITICAL IDEOLOGIES IN ARAB COUNTRIES}

Islam in Arab countries for many years, had a great potential at local communities. As he then contributed to the shaping of societies, as Islamic groups see societies negatively as a whole, and in their interaction, some Islamic currents flourished and attended that they could interact with political reality, while most did not get them, or lost Due to the absence of dynamic thinking from political practice.

In the last 30 years, Islamic currents have begun and emerging more intensely than the past in Arab countries, some groups are very violent, such as the appearance of the Islamic state (ISIS), which do not enjoy wide popularity across the Middle East. In general, Islamic groups mix the relationship between religion and politics. Regarding other moderate Islamic Sunni groups operating in the political framework, especially in Egypt, Tunisia, such as today, or marginalize either forced to reconsider their strategies. The failure of the Muslim Brotherhood in Egypt is partly due to the fact 
that the team focused too much in Sharia (it is a general and inclusive term, includes all the doctrinal, ethical and practical decisions of religion). as a slogan rather than in the objective intervention. On the contrary, another group such as salads, are those who in recent decades determined their objective intervention under Sharia Law without political slogans, resulting in an environment hostile to Islamic groups. Unlike Iran's Shiites, political power remains alive, thanks to political ideology that almost synonymous with religious science, also Iranian society is still a religious society, even when the confidence of today's generation in the official religious authorities is much smaller than in the previous generation.

Sunni and Shiites have a traditional disagreement on the ideological interpretation of Islam expanded and continued to date, in relation to the nature of modern life, political, economic, social and spiritual life in Islamic countries. The term Islamic nation does not mean more than the involvement of a group of people in a religion, and may be different at all, starting from the religion itself in which they are divided into sectors and common names with different national associations, their different countries and differences in internal and foreign policy but also.

\section{RELIGION AND POLITICAL IDEOLOGIES IN EUROPE}

Liberalism is perhaps, the most fundamental principle of the European Union, as well as modern urban Western democracy. Liberalism is based on democracy, human rights, pluralism and freedoms of all kinds, which makes the EU one of the most liberal political entities in the international system. Religions are perceptions and beliefs in political liberalism. While the process of strengthening or reducing the intervention role of a religion is not in political actions, but it is fully dependent on the acceptance or rejection of their role in specific cultural and social environments, therefore religions are perceived as dynamic cultural elements that make up Strong basis for a society, which seeks through the tolerance and understanding of the different, coexistence and acceptance of the other.

History and experience in the European Union have shown that immigrants have somehow affected liberal policies within it in many Western European countries, while in Eastern Europe, traditionally strong nationalist feelings and ambition to maintain their own culture, As in Hungary, they have created more popular immigration policies. With this result, many have doubts as to the extent to which the EU can be a liberal community on migration. For the recent refugee crisis, several countries of the European Union have otherwise worked, some states have pursued to be favorable to migrants for economic reasons, others have been pursuing policies for years to ensure that their liberal values have been maintained. A third category of non-western societies has been unhappy with immigration from the beginning. On the part of migrants and refugees, studies have shown that the second generation, mainly Muslims, migrants tend to collide cultures, others argue that it is a conflict between tradition and modernity, and a third group supports it as a conflict between radical liberalism and radical Religion.

Democracy is a system of governance of society, based on the principle of majority of the decisions of the dominant political body (the Municipality / People) of the citizens under Catholic and Secret Voting. This is, for the decision-making process, which practically ensures the rights, freedoms, recognition of the other, the value of life and the inviolability of dignity. Respect and protection of the value of man is the primary obligation of the state.

The European Union in its operation is based on representative democracy. European citizen enjoys civil rights, and has the right to vote and eliminate. Individual freedoms, such as respect for privacy, freedom of thought, religion, expression and information protected by the EU Charter of Fundamental Rights. The rule of law and values in a society where social inclusion is prevalent, tolerance, justice, solidarity and non-discrimination are an integral part of the European way of life. All EU Member States have democratic governance systems in a local and regional dimension that start from federations or state and end up in the unified states.

\section{ISLAMOPHOBIA IN EUROPE}

The term Islamophobia comes from Latin Language, Islamophobia, which means pathological fear for Islam. It is a mine definition that belongs to the field of psychology and therefore refers to Phobia as a psychological disease, that is, there is no reason for panic and fear, but it is just an illusion that controls the patient and imagines that there is a threat. Islamophobia as a cultural racism is a specific 
form of distinction addressed to Muslims, suggests that these are discrimination against religion than for people. Indeed, many attacks on the rhetoric and some right groups, as well as strong seculars justify their criticism. Some emphasize Islamophobia as a racism of Islam or Muslims. Others become Islamophobia with structural terms, where it is a built-in feature of social rules and institutional governance, and this is intensified in the modern Western European framework characterized by fears of terrorism and radicalization related to certain forms of Islam.

Islamophobia has become a weapon and an approved policy, and a lively reality in the West and Europe, especially, not only through the system of laws that violate the rights of Muslims, but has been accepted and legitimate to criticize Muslim migrant groups in the West Under the coverage of liberal values, such as freedom of expression and women's rights, and irony is that this was supported by the wide range of media so that the ratio of racism and hostility against Muslims seem normal. and acceptable socially and politically, and discrimination against Muslims to become a fearless part of the political climate that prevails in Europe.

European countries are concerned about these developments as they endanger harmonious cohabitation. Consequently, they have taken measures and have adopted laws to combat extremist forces, to reduce radicalization and improving the integration of Muslims in host countries.

European concern about the conflict between migration and terrorism, although it is possible in previous events that shook the European capitals, is excessive at the point that the impetus is intended to justify the European tendency to adopt an excessive approximation of security when dealing with the problem of migration, as well as to justify the wave of racist acts exercised against immigrants in host countries. The pretext of terrorism was only a tool, a pretext and an ideology, used by antiIslamic forces whenever the need arises to harm migrants.

European awareness of the need to withdraw religion from public life and modernization leads inevitably to cosmosis so, although Europe has accepted Muslim migrants, they have not accepted them as it is in their religion and culture, which they claim to be essentially Incompatible with the universal values on which Europe is based, the values of freedom, democracy and populism. The Muslim Immigrant, according to the image showing the media, is not a citizen, but the other, regardless of the generation to which he belongs, the nationality he bears the ideas with which he has. This belief is increasing when violent incidents occur, such as terrorist acts by European Islamic origin or sabotage acts such as those in Spain, France or Britain enemy. Thus, Islam becomes a container for what West does not want and for those who are afraid so that immigrants as a potential threat and terrorism for the West and its interests.

\section{CONCLusions}

It is worth noting that the groups of refugees and immigrants in Europe, although most of them come from Arab and Islamic countries, but differences between social, religious and cultural terms. Differences, for example, in Syrian society, and Palestinian society are small while among the Afghan society and Indian society are not small differences and the same applies to Asian and African societies. The non-harmonious group of refugees and immigrants affects their social inclusion and perhaps the degree of religion conservatism makes the dialogue difficult. Also, as long as it is relaxed in faith a society the more easily accept others. The fanaticism of the religion of one and other society prevents the process of integrating refugees and immigrants.

It is noted that religious ideology involves its strength thanks to faith in it and its difference from political ideologies, which are changing, is that the ideology of religion is subject to its divine origin. Religious political ideology does not seek the power of religion, but seeks its power in the name of religion exploit folk religious consciousness, and that is why it is very difficult to see a cosmic Arab state, or to separate religion from politics Account the tools used by religion for its superiority on humanitarian, moral, protection of society's spiritual life.

There is a division in the policies of the European Union, as regards the internal legislation on asylum procedures for refugees, although it issues EU immigration policy at intervals, and migrant cultures are currently colliding, especially Muslim origin They often support different values and lifestyles, than those that apply to Western Europe, which may troubleshoot their social inclusion in liberal societies if no liberal values and principles are not followed. 
Finally, it is noted that the overwhelming majority of Muslims in Europe are migrants first to third generation, and newly entrant refugees, which created problems in Europe, with the appearance of extremely anti-Muslim parties. European states must make every effort to promote their integration from one, and on the other hand, Muslims must contribute by showing their commitment to their new installation countries.

\section{REFERENCES}

[1] Polycarbos Karamouzis. The sociology of religion between education and society. Greek academic electronic components and aids. ISBN: 978-960-603-277-6. SAV, 2015.

[2] Thanos Lipovic. The polytheism of values: Max Weber. https://ejournals.epublishing.ekt.gr/index. php/sas/article/viewfile/450/447.pdf.

[3] Nancy Fraser. Social Justice in the Age of Identity Politics: REDISTRIBUTION, RECOGNITION, Participation. December 1998. ISSN NR. 1011-9523. DISCUSSION PAPER FS I 98 -108.

[4] UNHCR. Religion as a reason for fear of prosecution in the application of Article 1a (2) of the 1951 Geneva Convention and / or Protocol 1967 on the status of refugees. At https://www.refworld.org/cgibin/texis/vtx/rwmain/opendocpdf.pdf?reldoc=y\&docid=4bb459922.

[5] University of Macedonia. Gathenidis Nikolaos, Doctoral Dissertation "The protection of cultural diversity in Europe: Equality policies, European values and the right to cultural identity. 2015 ". http://thesis.ekt.gr/thesisbookReader/id/42863\#page/1/mode/2up.

[6] Jacob Olidort. The State (s) of Ideology in the Middle East: Introduction. WASHINGTON INSTITUTE FOR NEAR EAST POLICY. 18 Feb 2016. On https://www.washingtoninstitute.org/policy-analysis/statesideology-middle-east-introduction.

[7] M. JALLOUL. LA PROBLÉMATIQUE DU DEVENIR ISLAMIQUE A PROBLEMATIC OF ISLAMIC CHANGE.

[8] LA PROBLEMÁTICA DEL DEVENIR ISLÁMICO. p. 41-46. Journals Openedition.

[9] On https://journals.openedition.org/insaniyat/8056?Lang=en.

[10] Arvanitis Christopher. Religion and political liberalism. Joint Publishing. 2019.

[11] Paula Hafner. Northern Michigan University. The Varying Degrees of Liberalism In Migration and Immigration Policy Within The European Union: Causes, consequences and classes. Conspectus Borealis. 2016. https://commons.nmu.edu/cgi/viewContent.cgi?article=1014\&context=conspectus_Borealis.

[12] Dimitris Charalambis. Emeritus Professor of Political Science, President of the Greek Political Science Society. What is democracy? Conditions for the assembly and guiding principles. 2019. https://www.syntagmawatch.gr/my-Constitution/ti-einaPothesis-sigrotisisisisisisisisfthidiries-arches/.

[13] John Loughlin. Cardiff University of Wales (UK). Local and regional democracy in the European Union. Committee of the Regions. European Commission. European Union. Done at Brussels 1990. https://engage/studies/documents/region.

[14] Thomas Sealy. University of Bristol. Islamophobia: With or Without Islam? https://doi.org/10.3390/ rel12060369. Published: 21 May 2021.

[15] BICHARA KHADER. Catholic University of Louvain, Louvain, Belgium. Article from the Book the search for Europe: Contrasting Approaches MUSLIMS IN EUROPE: THE CONSTRUCTION OF A "PROBLEM". On https://www.bbvaopenmind.com/en/articles/muslims-in-europe-the-construction-of-aproflem/.

[16] MUSLIM IMMIGRANTS IN BETWEEN ISSUES OF Identity and Terrorism. The Arab Democratic Center. 26. May 2017. On https://www.democraticac.de/?p=46765.

[17] Roy, Olivier. Rethinking The Place of Religion In European Secularized Societies: The Need For More Open Societies. European University Institute. On https://cadmus.eui.eu//handle/1814/40305. 


\section{AUTHOR'S BIOGRAPHY}

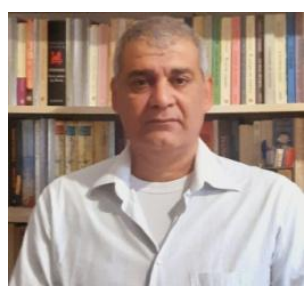

Ouael Sarsour, holds a degree in Business Administration at the University of Macedonia (Thessaloniki - Greece).

Master's degree in European societies and European integration on postgraduate work: "The refugee crisis since 2015 onwards", the Department of Sociology School of Social Sciences - University of the Aegean in Mytilene.

Since April 2020, in the same Department-School of the University of the Aegean, he is a researcher and a doctoral candidate entitled "The factors that affect the social inclusion of Arabs Refugees and Immigrants in Greece".

Professionally, he has worked in Finance and Administration. Now he is working in intercultural mediation.

Citation: Ouael Sarsour. "The Role of Religion in the Social Inclusion of Arab Refugees and Immigrants in Europe" International Journal of Humanities Social Sciences and Education (IJHSSE), vol 8, no. 10, 2021, pp. 69-74. doi: https://doi.org/10.20431/2349-0381.0810008.

Copyright: (c) 2021 Authors. This is an open-access article distributed under the terms of the Creative Commons Attribution License, which permits unrestricted use, distribution, and reproduction in any medium, provided the original author and source are credited. 